\title{
Screening for Hepatocellular Carcinoma in Patients with Hepatitis B
}

\author{
Yashasavi Sachar ${ }^{1}$, Mayur Brahmania ${ }^{1,2}$, Renumathy Dhanasekaran ${ }^{3}$ and Stephen E. Congly ${ }^{4,5, *(\mathbb{D})}$ \\ 1 London Health Sciences Center, Department of Medicine, Division of Gastroenterology, Western University, \\ London, ON N6A 5A5, Canada; ysachar2023@meds.uwo.ca (Y.S.); mayur.brahmania@lhsc.on.ca (M.B.) \\ 2 Centre for Quality, Innovation and Safety, Schulich School of Medicine \& Dentistry, Western University, \\ London, ON N6A 5W9, Canada \\ 3 Department of Medicine, Division of Gastroenterology and Hepatology, Stanford University, \\ Stanford, CA 94305, USA; dhanaser@stanford.edu \\ 4 Department of Medicine, Division of Gastroenterology and Hepatology, Cumming School of Medicine, \\ University of Calgary, Calgary, AB T2N 4Z6, Canada \\ 5 O'Brien Institute of Public Health, University of Calgary, Calgary, AB T2N 4Z6, Canada \\ * Correspondence: secongly@ucalgary.ca
}

check for

updates

Citation: Sachar, Y.; Brahmania, M.; Dhanasekaran, R.; Congly, S.E. Screening for Hepatocellular Carcinoma in Patients with Hepatitis B. Viruses 2021, 13, 1318. https:// doi.org/10.3390/v13071318

Academic Editor: Philippe Gallay

Received: 15 June 2021

Accepted: 5 July 2021

Published: 8 July 2021

Publisher's Note: MDPI stays neutral with regard to jurisdictional claims in published maps and institutional affiliations.

Copyright: (c) 2021 by the authors. Licensee MDPI, Basel, Switzerland. This article is an open access article distributed under the terms and conditions of the Creative Commons Attribution (CC BY) license (https:/ / creativecommons.org/licenses/by/ $4.0 /)$.

\begin{abstract}
Chronic hepatitis B (CHB) infection is a significant risk factor for developing hepatocellular carcinoma (HCC). As HCC is associated with significant morbidity and mortality, screening patients with $\mathrm{CHB}$ at a high risk for HCC is recommended in an attempt to improve these outcomes. However, the screening recommendations on who to screen and how often are not uniform. Identifying patients at the highest risk of HCC would allow for the best use of health resources. In this review, we evaluate the literature on screening patients with $\mathrm{CHB}$ for $\mathrm{HCC}$, strategies for optimizing adherence to screening, and potential risk stratification tools to identify patients with $\mathrm{CHB}$ at a high risk of developing HCC.
\end{abstract}

Keywords: hepatitis B; hepatocellular carcinoma; cost-effectiveness; screening; risk stratification; alpha-fetoprotein; adherence; ultrasound

\section{Introduction}

Liver cancer is a leading cause of morbidity and mortality on a global scale, with approximately 30,000 deaths expected annually in the United States in 2020 [1], and significantly increased incidence rates modelled by 2030 world-wide [2]. The most common form of liver cancer is hepatocellular carcinoma (HCC), which accounts for approximately $75-85 \%$ of liver cancer cases [3]. HCC is within the seven most common cancers worldwide, and the third largest cause of cancer-induced mortality [4]. The leading cause of HCC worldwide is chronic hepatitis B virus (CHB) infection, which affects more than 250 million people world-wide [5]. Although every patient with $\mathrm{CHB}$ is at an elevated risk of developing HCC, this does not mean that each patient is at an equivalent risk. As demonstrated by the COVID-19 pandemic, surveillance programs can be easily disrupted. However, effective models of risk stratification can ensure that remaining resources are optimally allocated to the prioritization and prevention for those at the highest risk until the system returns to full capacity [6]. Several scoring systems have been created in an attempt to optimize the distribution of patients into different risk profiles, based on patient characteristics, along with viral characteristics [7]. The heterogeneity of the global CHB induced HCC population has made it difficult to develop a unified risk-scoring system, with differences among methodologies in terms of how these scoring systems identify, score, and evaluate relevant variables. This review aims to provide a comprehensive summary for the clinician, regarding screening for HCC in patients with $\mathrm{CHB}$. Topics covered include reviewing the epidemiology of $\mathrm{HCC}$ in $\mathrm{CHB}$, the state of research regarding screening patients with $\mathrm{CHB}$ for HCC, a summary of current guidelines for screening, highlighting the key literature 
regarding cost-effectiveness of screening, identifying barriers to adherence, discussing strategies to improve screening, and providing a complete and comprehensive analysis of existing HCC risk stratification models in patients with HBV.

\section{Epidemiology of Liver Cancer and HBV}

Chronic hepatitis B (CHB) infection accounts for $44-55 \%$ of HCC diagnoses worldwide, and those infected are at a 20-fold increased risk when compared to a non-infected population [8]. Although the prevalence of HCC in patients with $\mathrm{CHB}$ varies between populations, rates as high as $23.2 \%$ have been previously reported in Asia-specific studies [9]. High prevalence CHB regions are often resource limited and have a low human development index [10]; some of the most endemic regions include the Amazon Basin, Africa, Central, and Southeast Asia [11]. The relationship between CHB and HCC is further exemplified by the elevated risk of developing HCC in endemic regions, with sub-Saharan Africa and Eastern Asia being responsible for $>80 \%$ of HCC cases [11]. This may change as HBV immunization programs gain stability in these regions [12]; however, there are limitations to its use as a prophylactic strategy against vertical transmission [13]. Although it is not a traditionally endemic region, the $\mathrm{CHB}$ population has been increasing in recent years in North America [14], with a 2020 study estimating approximately 1.59 million people having CHB in the United States of America [15]. This increase is mainly driven by external factors, such as an influx of immigration from countries with a high $\mathrm{CHB}$ prevalence. The increase in CHB has been paralleled by an increase in HCC, which is now the fastest growing cancer in the United States in terms of incidence [1]. Furthermore, the proportion of HCC cases resulting from CHB has also increased, with one American study demonstrating that the proportion of CHB-induced HCC cases grew from $4 \%$ to $21 \%$ [16]. Therefore, as CHB and HCC become more common in western populations, the burden of disease has shifted from its traditional localized distribution to a global impact.

\section{Screening for Hepatocellular Carcinoma}

\subsection{Rationale for Screening}

The rationale for any screening strategy is to identify patients at earlier stages of disease where treatment has a higher likelihood of success, as well as to identify risk factors that increase the risk of developing the disease, as to allow for interventions [17]. Factors to consider in the evaluation of any screening strategy are whether it is a disease of concern, and whether the screening test is effective, reasonable in cost, and improves outcomes $[17,18]$. Screening for HCC clearly meets these criteria, given that HCC is a public health concern, leading to a significant loss of life years and quality of life [19].

Currently, an ultrasound with the possibility of adding alpha-fetoprotein are recommended as the screening strategies for HCC [20-24]. At this time, there are only three randomized clinical trials comparing HCC surveillance versus no surveillance, with conflicting results related to methodological challenges. The first trial studied patients from Shanghai that were employed in factories, schools or private enterprises, with CHB or chronic liver disease; they were allocated by cluster sampling into those who received AFP and an ultrasound every 6 months $(n=8109)$ and a control group $(n=9711)$ enrolled between 1992-1994 [25]. In screened patients, 38 patients with liver cancer were identified after 12,038 person-years, and in the control group 18 patients were diagnosed after 9573 person-years. Patients identified in the screening group had a 1-year survival of $88.1 \%$ and two-year survival of $77.5 \%$, and HCC were found at an earlier stage than the control group; the control group had a $0 \% 1$-year survival. Although this study estimated an average cost of \$1500 USD per early-stage HCC diagnosis, the number of false positive screening results was not reported, and would likely have increased the procedural and administrative cost of executing this program.

A similar study was conducted through 1993-1995 in Shanghai, consisting of 18,816 patients aged 35-59 with chronic hepatitis B. Participants were randomly allocated to screening (9373) with alpha-fetoprotein and ultrasounds every 6 months, versus a control 
group (9443) [26]. The surveillance arm identified 86 cases with 32 deaths from HCC, and the control arm had 67 cases with 54 deaths, leading to a risk ratio of 0.63 (95\% CI $0.41-0.98)$ for the screening arm. Notably, this trial has been criticized for a lack of information about each group's baseline characteristics, and how the outcome of death from liver cancer was defined [27]. Furthermore, the cohort likely has significant overlap with the last study by Yang et al. [25], given the population characteristics and time frame of recruitment.

The third randomized trial focused on men aged 30-69 between 1989-1995 in Jiangsu Province, China, using alpha-fetoprotein (AFP) levels every 6 months $(n=3712$, mean follow-up 61.9 months) with a threshold of $20 \mu \mathrm{g} / \mathrm{L}$, versus a control group ( $\mathrm{n}=1869$, mean follow-up 62.8 months) [28]. Adherence rates for obtaining AFP were low at about 30\%. A significantly larger number of cases were identified in the screening arm vs. the control arm at early stages (BCLC Stage 0-A [29]), with early detection rates of $29.6 \%$ and $6.0 \%$, respectively. The 5 -year survival between the groups did not differ at $4 \%$, and the risk ratio in the screening arm was not statistically significant (RR 0.83; 95\% CI 0.68-1.03), which may be related to the limited antiviral therapy available at the time of the study. The study has been criticized for the unclear randomization and allocation concealment techniques that were used [27].

A meta-analysis from 2014 which included the second and third trial, as well as 18 observational studies examining the role of screening in patients with chronic liver disease, concluded that it was uncertain whether systematic surveillance improved patient survival, and highlighted that more data were required given the relatively few studies on the CHB population [27]. A second meta-analysis published by Singal et al. [30] looking at patients with cirrhosis, suggested that the use of ultrasound was associated with a higher probability of diagnosing cancers at an earlier stage (OR 2.08, 95\% CI 1.80-2.37) and improved survival (OR 1.90; 95\% CI 1.67-2.17). These differences remained significant when accounting for lead time bias; however, only three publications looked at HBV patients in particular, with no subgroup analysis performed.

More recent epidemiological studies have shown potential survival benefits of HCC surveillance. One Canadian trial examined outcomes in patients with viral hepatitis diagnosed with liver cancer, and the impact of ultrasound screening prior to their diagnosis [31]. The 5-year survival in patients receiving routine surveillance (at least an ultrasound annually) was $31.93 \%$ (95\% CI $25.77-38.24 \%$ ) versus $20.67 \%$ (95\% CI $16.86-24.74 \%$ ) in patients who were not screened. Moreover, surveillance was associated with a mortality risk of 0.76 (95\% CI 0.64-0.91), which indirectly supports the role of screening. Similarly, in patients with all-cause cirrhosis, screening for HCC has been suggested to have potential survival benefits [32-34]; although, a case-control study of the US Veterans Affairs cohort did not show a survival difference between those screened with ultrasounds and those who were not [35]. Current recommendations from the US National Cancer Institute suggest that screening patients at an increased risk does not lead to a decrease in mortality from HCC, as shown by fair quality evidence that is based on lead and length time bias [36].

Ideally, a randomized clinical trial in an attempt to best answer this question would be useful; however, this is unlikely to happen, given ethical concerns about the harm associated with no surveillance, as patients and practitioners prefer surveillance [37]. Further, answers to the true benefit of screening through cohort/case-control trials focusing on the role of screening patients with $\mathrm{CHB}$ will be important, given the limited high-quality literature to date. One potential barrier to a universal consensus regarding screening is the variation in efficacy of screening between regions. This is due to internal population factors, such as the prevalence of $\mathrm{CHB}$ and risk of tumor development based on prognostic factors of disease severity, in addition to health care resources available in the region. For example, although a male cohort between the ages of 70-79 may be at the highest risk of developing HCC, Japanese, African, and Chinese populations are skewed as significantly younger [21]. These differences in epidemiology are mirrored by regional differences in post-diagnosis outcomes [38], dependent on factors, such as availability of therapeutics and patient health status. Consequently, any analysis regarding the impact of surveillance 
may be limited to regional applicability, and if an RCT is conducted in the future it would be best to involve multiple regions, in an effort to create a generalizable scope of study.

\subsection{Current Society Guidelines for HCC Screening}

Currently, it is recommended by all major hepatology international societies to screen for liver cancer in patients with CHB deemed to be high risk with the use of abdominal ultrasound every 6 months, with variable recommendations regarding the inclusion of AFP. Although these guidelines are largely similar, there are some minor differences, i.e., the use of AFP and when to screen patients from an African background. We summarize the current society guidelines in Table 1.

Table 1. Summary of International HCC Screening Recommendations.

\begin{tabular}{|c|c|c|c|c|}
\hline 1 & APASL 2017 & AASLD 2018 & CASL 2019 & EASL 2018 \\
\hline \multicolumn{5}{|c|}{ Screening Strategy } \\
\hline Abdominal ultrasound (US) & \multicolumn{4}{|c|}{ Recommended every 6 months } \\
\hline Alpha-fetoprotein (AFP) & $\begin{array}{l}\text { Recommend AFP every } \\
6 \text { months with US }\end{array}$ & $\begin{array}{l}\text { Can consider AFP every } \\
6 \text { months with US }\end{array}$ & \multicolumn{2}{|c|}{ AFP use not recommended } \\
\hline \multicolumn{5}{|c|}{ Patients for Which Screening is Recommended } \\
\hline Patients with cirrhosis & Yes & Child Pugh A/B & Yes & Child Pugh A/B \\
\hline Asian men with chronic hepatitis B & & $>40$ years old & & \\
\hline Asian women with chronic hepatitis B & & $>50$ years old & & PAGE-B $\geq 10$ \\
\hline African men/women with chronic hepatitis B & $>20$ & $>40$ & $>20$ & \\
\hline Family history of hepatocellular carcinoma & Yes & Yes & Yes, >40 years old & No \\
\hline Co-infected with hepatitis delta virus (HDV) & No & Yes & No & No \\
\hline $\begin{array}{c}\text { Co-infected with human immunodeficiency } \\
\text { virus (HIV) }\end{array}$ & No & No & $>40$ years old & No \\
\hline
\end{tabular}

${ }^{1}$ APASL: Asian Pacific Association for the Study of the Liver; AASLD: American Association for the Study of Liver Diseases; EASL: European Association for the Study of the Liver; CASL: Canadian Association for the Study of the Liver; PAGE-B: platelets, age, genderHBV score.

AFP is a glycoprotein produced primarily during the ontogenesis of the yolk sack and fetal liver, with a suppressed expression following birth. However, increased AFP production has been associated with reparative growth following liver damage [39], as well as oncogenesis, acting as a pro-proliferative protein involved in regulating apoptosis, growth, and angiogenesis [40]. Due to its association with abnormal hepatocyte proliferation, AFP elevations are well documented in both malignant liver disease [40] and nonmalignant liver diseases, such as acute hepatic failure [41] and CHB [42]. Unfortunately, the use of AFP as a screening tool remains unclear. A recent meta-analysis evaluated the effectiveness of screening with ultrasound versus using ultrasound and AFP in detecting early cancer [43]. Thirty-two studies were identified in this study (consisting of 13,367 patients). Ultrasound identified any stage of HCC with $84 \%$ sensitivity $(95 \%$ CI $76-92 \%)$, while identifying early-stage HCC with $47 \%$ sensitivity (95\% CI 33-61\%). The addition of AFP to ultrasound increased the sensitivity to $63 \%$ (95\% CI 48-75\%) for early-stage HCC, and to $97 \%$ (95\% CI 91-99\%) for all stages of cancer. Subsequently, the addition of AFP reduced the specificity to $84 \%$ (95\% CI $77-89 \%$ ) from $92 \%$ (95\% CI $85-96 \%)$. There were some limitations to this meta-analysis, as it had no studies that were looking at survival. Moreover, most studies only looked at HCC at any stage vs. early HCC, which may overestimate surveillance test performance. Furthermore, negative screening tests were not confirmed by another modality, which may lead to verification bias. Overall, it is critical to note that using AFP by itself is not recommended, as it has poor sensitivity and specificity [44].

\subsubsection{Asian Pacific Association for the Study of the Liver (APASL)}

The 2017 APASL guidelines [24] recommend abdominal ultrasounds with AFP every 6 months for HCC screening in patients with CHB cirrhosis in Asian females $>50$ years, Asian males $>40$ years, patients of African background $>20$ years, and in patients with a 
family history of HCC (no specific starting age recommended) (Table 1). The AFP threshold recommended is $200 \mathrm{ng} / \mathrm{mL}$ to obtain the optimal positive likelihood ratio.

\subsubsection{American Association for the Study of Liver Diseases (AASLD)}

The 2018 AASLD guidelines [22,23] recommend abdominal ultrasounds every 6 months with or without AFP. The latter is a significant change from the 2010 guidelines [45], which explicitly recommended against AFP, due to concerns with false positives and subsequent testing. The AFP threshold recommended by the AASLD is $20 \mathrm{ng} / \mathrm{mL}$. High risk groups that are recommended for HCC screening include patients with cirrhosis secondary to $\mathrm{CHB}$ with either Child-Pugh A or B; Child-Pugh C patients who are non-transplant candidates are excluded, as treatment would likely not be feasible. Other patients recommended for screening include Asian females $>50$ years, Asian males $>40$ years, patients of African background $>40$ years, patients with a first-degree relative with a history of HCC (no specific starting age recommended), and patients co-infected with hepatitis delta (HDV) (no specific starting age recommended) (Table 1 ).

\subsubsection{European Association for the Study of the Liver (EASL)}

The 2018 EASL guidelines [21] advocate screening high risk patients with abdominal ultrasounds every 6 months, and do not recommend using AFP routinely, due to concerns regarding false-positive results in the context of active liver inflammation. Patients recommended for screening include those with Child-Pugh A or B cirrhosis; Child-Pugh C cirrhosis awaiting liver transplantation; and patients with chronic hepatitis $\mathrm{B}$ determined to be at an intermediate or high risk of developing HCC, based on PAGE-B classes for those of Caucasian background (Table 1).

\subsubsection{Canadian Association for the Study of the Liver (CASL)}

The 2019 CASL guidelines [20] recommend performing abdominal ultrasounds every 6 months for patients deemed to be at a high risk for developing HCC. This includes patients with $\mathrm{CHB}$ cirrhosis, Asian females $>50$ years, Asian males $>40$ years, patients of African background $>20$ years, and patients with a family history of hepatocellular carcinoma starting at age 40 , as well as patients with HIV co-infection $>40$ years (Table 1).

\subsubsection{Guideline Based Approach to Co-Infection}

All four guidelines discussed above highlight the potential impact of co-infection with hepatitis $\mathrm{C}$ virus (HCV), HDV or HIV as a risk factor for developing HCC, although each set of guidelines emphasizes a different viral co-infection. The data for the impact of co-infection on its development is strongest in HDV [46,47], with data for HCV [48] and HIV [49,50] being weaker. Although there may be an increased risk with co-infection, there is little evidence regarding how screening guidelines should be changed. This likely explains the lack of explicit comment throughout guidelines, regarding the impact of co-infection and HCC screening; this is an important area for further research. That being said, it is important to recognize that both patients with mono-infection and significant co-infection undergo the same HCC surveillance protocol under the previously mentioned guidelines, suggesting the primary driver for surveillance in this situation is the oncogenic potential of CHB.

\subsection{Cost Effectiveness of Screening Strategies for HCC}

A key component of any screening strategy is ensuring it offers good value for money; that is, the strategy is cost effective. The majority of studies evaluating the cost-effectiveness of screening consider patients with cirrhosis, with a minority of studies looking at hepatitis $\mathrm{B}$ being mostly focused on Asian populations [51]. In studies comparing screening using abdominal ultrasound +/ - AFP with no screening [52-56], screening programs were cost effective in all but one study [55]. 
There are two recent studies evaluating the cost effectiveness of imaging-based screening, as compared to no screening at all. A Taiwanese based study evaluated the cost effectiveness of screening patients with $\mathrm{CHB}$ with ultrasounds every 6 months versus no ultrasounds [56]. The base case was a 50-year-old individual who was followed over a 25year time horizon. Screening had a cost of \$5912.37 USD for 13.78 years of life, as compared to $\$ 557.10$ for 13.53 years of life in the unscreened arm, working out to an incremental cost effectiveness ratio of $\$ 20,856.25$ / year of life gained. Sangmala and colleagues expanded this analysis, and evaluated multiple screening strategies in a Thailand population of patients with CHB between the ages of 40-60 with a lifetime time horizon [52]. The strategies evaluated in this model included abdominal ultrasound, AFP and US, computed tomography $(\mathrm{CT})$, and magnetic resonance imaging (MRI) at either a 6-monthly or 12-monthly frequency. Without any form of screening, only 6.24 quality adjusted life years (QALY) were gained. The use of ultrasound or ultrasound and AFP for HCC screening were found to be the most cost effective strategies. Notably, CT and MRI based strategies were not cost effective.

A recent analysis evaluating the cost effectiveness of screening compares abdominal ultrasound with or without AFP for HCC screening. This analysis is novel in its consideration of the potential harm of unnecessary tests, due to false positives [57], which is not considered in previous studies. The cohort studied were patients with compensated cirrhosis over a lifetime horizon. The most cost effective strategy for the cohort was using US with AFP, with a cost of \$1,254,173.20 USD for 6.02 QALY; both using US and no surveillance in this cohort was more expensive and less effective than US with AFP. Modelling the impact of false positive testing in the CHB population is an important area to evaluate, until then, extrapolation from the available evidence is required.

\section{Challenges with Screening Adherence}

Adherence by patients to screening programs is a key indicator of success. Unfortunately, a major challenge with HCC surveillance programs is that of poor adherence rates. A study from Washington State looking at 1137 patients with cirrhosis highlights this challenge. Over a 2-year period, 33\% of this group had at least one ultrasound (intermittent surveillance), and those with $\mathrm{CHB}$ cirrhosis were found to be more likely to undergo surveillance. Notably, only $2 \%$ of patients in this study underwent consistent surveillance, defined as having an ultrasound every 6 months [32]. A recent meta-analysis looking at screening for patients at a high risk of developing HCC identified 22 studies involving 19,511 patients, showing an overall adherence rate of 52\% (95\% CI 38-66\%). Looking at the subset of studies of patients with CHB (4 trials, 2651 patients), the adherence rate was significantly lower $(32 \%, 95 \%$ CI $13-51 \%)$. A subsequent meta-analysis focusing on patients with cirrhosis identified 29 studies ( $\mathrm{n}=118,779$ patients) with a surveillance rate of $24 \%$ (95\% CI 18.4-30.1); however, higher surveillance rates were observed when patients were seen by gastroenterologists and/or hepatologists [58].

Screening programs are complex, and there are many reasons why lower adherence rates to screening are observed. Simply, there are system, provider, and patient-based factors, as outlined in Figure 1. Physician failure to order HCC surveillance was the most common reason for patients not receiving surveillance in two studies $[59,60]$, with a separate investigation of physician surveillance practices finding only $22 \%$ relied on biannual imaging for HCC surveillance [61]. However, patient-driven non-adherence remains a significant determinant of surveillance inconsistency, with Singal et al. estimating patient non-adherence accounted for $<10 \%$ of adherence failures [62] in their study. Patient factors can be further divided into those that are related to feasibility (i.e., cost, insurance coverage [62], difficulty navigating system, transportation [63]) and patient perceptions (i.e., knowledge regarding need for surveillance, HCC presentation, management [63]). Both patient and provider factors are further exacerbated by systemic flaws, with issues related to supporting surveillance infrastructure and clinical care network [64], identified by existing studies. 


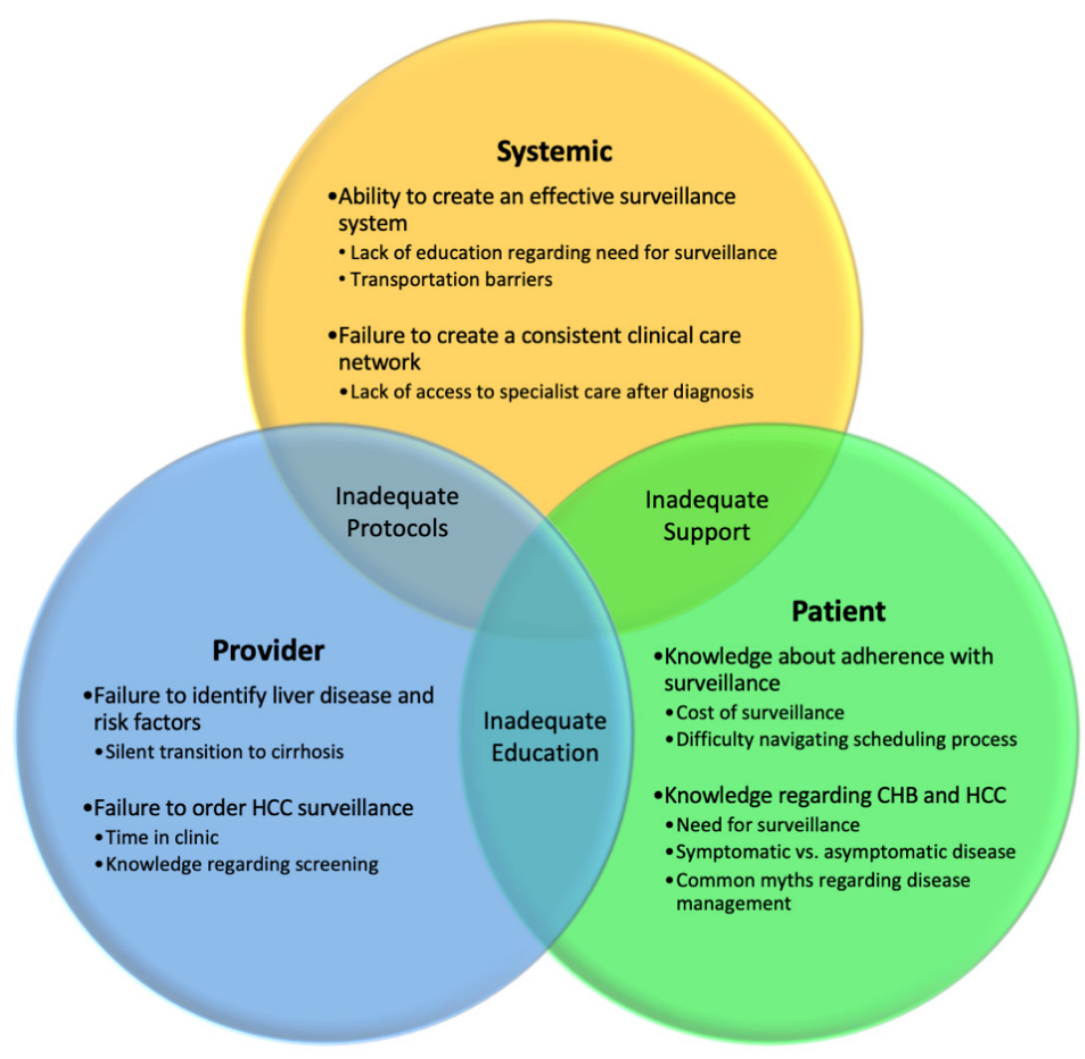

Figure 1. Factors Associated with Decreased Adherence to HCC Screening $[37,59,65,66]$.

Methods to Improve Adherence

A number of strategies have been studied in an attempt to improve adherence to HCC screening, including the education of primary care providers, nurse led clinics, mailed outreach, and radiology led programs [58]. Although all of these techniques have merit, the impact of these strategies are variable in efficacy. There have been four studies utilizing a post-intervention outcome of the proportion of patients meeting the gold-standard of having ultrasounds every 6 months. A randomized control trial evaluating outreach letters by mail showed that the rate increased from a baseline of $7 \%$ to $21 \%$ in the intervention arm [67]. Moreover, systematic changes may be associated with higher rates of surveillance, although likely coming at a higher cost. For example, in Australia, the introduction of a nurse-led clinic led to 53\% of patients seen in the clinic having appropriate ultrasounds [68], while a more intense system redesign and patient education program led to $63 \%$ of patients being screened [69]. From the radiology provider side, a radiology recall program in the United Kingdom [70] led to $46 \%$ of patients achieving appropriate screening. There is no one-size solution, but likely a structured intervention whereby the payer, patient, provider, and system will be important to increase the adherence rate of screening.

\section{Risk Stratification Systems for HCC Risk in Patients with HBV}

When comparing the various models of risk assessment, there appears to be some common areas of contention, which are addressed differently by different models. Risk stratification scores for HCC risk in HBV have been previously reviewed [71]. Here, in Tables 2 and 3, we present an updated critical summary of all published models of HCC risk assessment in patients with CHB. The majority of studies assessed in this review involve risk models, generated using homogenous populations. Although this is a result of the relatively homogenous populations in some of the countries in which these studies were generated (i.e., South Korea, Taiwan), this limits the utility of these models as international standards for HCC surveillance. In comparison, models generated in western countries, such as PAGE-B, have an advantage in terms of generalizability, as their study population for $\mathrm{CHB}$ often has a greater degree of ethnic 
diversity. However, as the number of models grows, newer studies such as the aMAP have been able to test their model in multiple populations of different ethnicities prior to publication, providing further support for the generalizability of their model. Although many studies report using gender as a risk factor, it is most likely that gender is incorrectly used, and this should be biological sex rather than the social concept of gender [72]; acknowledging this, we report the criteria as provided by the original publication. Ultimately, the majority of risk assessment models were reliant on follow-up studies, validating them in other population groups to strengthen their argument for generalizability.

Table 2. Critical Analysis of Untreated Patient Risk Assessment Models.

\begin{tabular}{|c|c|c|c|}
\hline Name $^{1}$ & Components & Strengths & Weaknesses \\
\hline IPM [73] & $\begin{array}{l}\text { Cirrhosis } \\
\text { Age } \\
\text { Chronic HCV infection } \\
\text { AFP } \\
\text { CHB infection } \\
\text { Chronic hepatitis } \\
\text { Alcohol consumption } \\
\text { Alcohol history } \\
\text { Sex } \\
\text { ALT }\end{array}$ & $\begin{array}{l}\text { - Variety of initial health } \\
\text { statuses (diagnosed cirrhosis, } \\
\text { CHB, carrier) } \\
\text { - } \quad \text { Prospective study } \\
\text { - } \quad \text { External validation in South } \\
\text { Korea }\end{array}$ & $\begin{array}{ll}\text { - } & \text { Ethnically homogenous cohort } \\
\text { - } & \text { Heavy alcohol use inconsistent } \\
\text { - } & \text { variable } \\
& \text { Limited antiviral available }\end{array}$ \\
\hline CU-HCC [74] & $\begin{array}{l}\text { Age } \\
\text { Albumin } \\
\text { Bilirubin } \\
\text { HBV DNA } \\
\text { Cirrhosis }\end{array}$ & $\begin{array}{ll}- & \text { Treatment status } \\
\text { heterogeneity } \\
-\quad & \text { External validation [75] } \\
- & \text { Higher AUROC than } \\
& \text { REACH-B, NGM1-HCC, } \\
\text { NGM2-HCC and GAG-HCC } \\
\text { in North American } \\
\text { population [76] }\end{array}$ & $\begin{array}{l}\text { - } \quad \text { Ethnically homogenous cohort } \\
\text { - } \quad \text { Did not discuss how missing } \\
\text { data handled [77] }\end{array}$ \\
\hline LSM-HCC [78] & $\begin{array}{l}\text { Age } \\
\text { Albumin } \\
\text { HBV DNA } \\
\text { LSM }\end{array}$ & $\begin{array}{ll}\text { - } & \text { Further refined CU-HCC } \\
\text { model } \\
\text { - } \quad \text { Treatment status } \\
\text { heterogeneity } \\
\text { - } \quad \text { TE LSM more accurate than } \\
\text { U/S [79,80] } \\
\text { - } \quad \text { Two-tier model risk } \\
\text { stratification }\end{array}$ & $\begin{array}{l}\text { - } \quad \text { Ethnically homogenous cohort } \\
\text { - } \quad \text { Did not discuss how missing } \\
\text { data handled [77] }\end{array}$ \\
\hline GAG-HCC [81] & $\begin{array}{l}\text { Version 1: } \\
\text { Gender } \\
\text { Age } \\
\text { HBV DNA } \\
\text { BCP mutations } \\
\text { Cirrhosis } \\
\text { Version 2: } \\
\text { Gender } \\
\text { Age } \\
\text { HBV DNA } \\
\text { Cirrhosis }\end{array}$ & $\begin{array}{ll}\text { - } & \text { Continuous nature of some } \\
\text { variables } \\
\text { - } \\
\text { 10-year NPV approaching } \\
\text { 100\% in cross validation [80] } \\
\text { - } \quad \text { Two-tier model for risk } \\
\text { stratification }\end{array}$ & $\begin{array}{ll}\text { - } & \text { Ethnically homogenous cohort } \\
\text { - } & \text { Same cohort for training and } \\
\text { validation }\end{array}$ \\
\hline REACH-B [82] & $\begin{array}{l}\text { Gender } \\
\text { Age } \\
\text { ALT } \\
\text { HBeAg } \\
\text { HBV DNA }\end{array}$ & $\begin{array}{ll}\text { - } & \begin{array}{l}\text { Derived in Taiwan and } \\
\text { applied to Hong Kong and }\end{array} \\
\text { South Korea } \\
\text { - } \quad \text { Large development cohort ( } \mathrm{n} \\
\text { = 3584) } \\
\text { - Used in APASL } 2012 \\
\text { guidelines for anti-viral } \\
\text { treatment eligibility [83] } \\
\text { - } \quad \text { Easy to evaluate and objective }\end{array}$ & $\begin{array}{ll}\text { - } & \text { Limited discrimination in } \\
\text { - } & \text { Caucasian population [84] } \\
\text { Not a validated predictor of } \\
\text { anti-viral treatment eligibility in } \\
\text { patients }>40 \\
\text { - } \quad \text { Three-tier stratification strategy } \\
\text { - } \quad \text { Developed in non-cirrhotic } \\
\text { cohort } \\
\text { - } \quad \text { Only overt cirrhosis considered } \\
\text { in exclusion criteria [82] }\end{array}$ \\
\hline
\end{tabular}


Table 2. Cont.

\begin{tabular}{|c|c|c|c|}
\hline Name $^{1}$ & Components & Strengths & Weaknesses \\
\hline aMAP score [85] & $\begin{array}{l}\text { Age } \\
\text { Sex } \\
\text { Albumin } \\
\text { Bilirubin } \\
\text { Platelet }\end{array}$ & $\begin{array}{ll}\text { - } & \text { Generated, calibrated, and } \\
\text { assessed in multiple } \\
\text { ethnicities } \\
\text { - } \quad \text { Large derivation (3688) and } \\
\text { validation }(13,324) \text { cohorts } \\
\text { - } \quad \text { Consistent performance with } \\
\text { multiple etiologies/ethnicities } \\
\text { - } \quad \text { Continuous variables } \\
\text { - } \quad \text { Easy to evaluate and objective } \\
\text { - } \quad \text { Performed better than } \\
\text { PAGE-B, LSM-HCC, } \\
\text { REACH-B, CU-HCC, } \\
\text { mREACH-B, mPAGE-B }\end{array}$ & 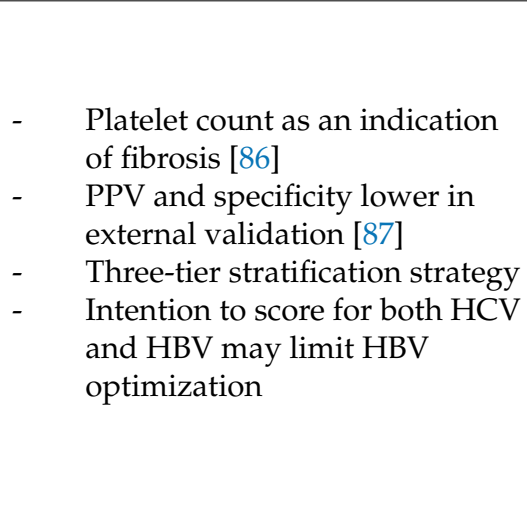 \\
\hline RWS-HCC [88] & $\begin{array}{l}\text { Sex } \\
\text { Age } \\
\text { Cirrhosis } \\
\text { AFP }\end{array}$ & $\begin{array}{ll}\text { - } & \text { Minimal calculation required } \\
\text { - } & \text { Treatment status } \\
\text { - } & \text { heterogeneity } \\
& \text { Multiple Asian cohorts } \\
\text { - } & \text { validation } \\
\text { Two-tier risk assessment } \\
\text { strategy }\end{array}$ & $\begin{array}{l}\text { - } \quad \begin{array}{l}\text { Ethnically homogenous cohort } \\
\text { - }\end{array} \text { Did not describe diagnosis of } \\
\text { cirrhosis } \\
\text { - } \quad \begin{array}{l}\text { Only patients with overt } \\
\text { cirrhosis }\end{array}\end{array}$ \\
\hline NGM1-HCC [89] & $\begin{array}{l}\text { Gender } \\
\text { Age } \\
\text { Family history of HCC } \\
\text { Alcohol consumption } \\
\text { ALT } \\
\text { HBeAg }\end{array}$ & $\begin{array}{ll}\text { - } & \text { Nomogram customizable for } \\
\text { individual risk characteristics } \\
\text { - } & \text { Large HCC cohort }(\mathrm{n}=3653) \\
\text { - } & \text { Intuitive clinical decision tree }\end{array}$ & $\begin{array}{ll}\text { - } & \text { Ethnically homogenous cohort } \\
\text { - } & \text { Alcohol consumption refers to } \\
\text { frequency not volume of alcohol }\end{array}$ \\
\hline NGM2-HCC [89] & $\begin{array}{l}\text { Gender } \\
\text { Age } \\
\text { Family history of HCC } \\
\text { Alcohol consumption } \\
\text { ALT } \\
\text { HBV DNA level }\end{array}$ & $\begin{array}{ll}\text { - } & \text { Nomogram customizable for } \\
\text { individual risk characteristics } \\
\text { - } & \text { Large HCC cohort }(\mathrm{n}=3653) \\
\text { - } & \text { Intuitive clinical decision tree }\end{array}$ & $\begin{array}{l}\text { - } \quad \text { Ethnically homogenous cohort } \\
\text { - } \quad \text { Alcohol consumption refers to } \\
\text { frequency not volume of alcohol }\end{array}$ \\
\hline LSPS [90] & $\begin{array}{l}\text { Liver stiffness } \\
\times \frac{\text { Spleen diameter }}{\text { Platelet Count }}\end{array}$ & 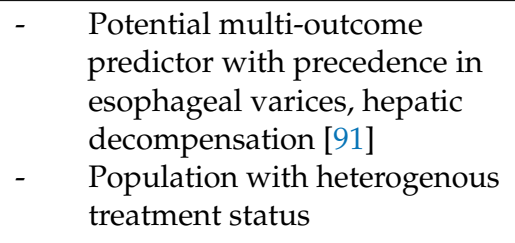 & $\begin{array}{ll}- & \text { Ethnically homogenous cohort } \\
- & \text { Self-reported alcohol } \\
\text { consumption was exclusion } \\
\text { criteria }\end{array}$ \\
\hline AGED [92] & $\begin{array}{l}\text { Age } \\
\text { Gender } \\
\text { HBeAg } \\
\text { HBV DNA }\end{array}$ & $\begin{array}{ll}\text { - } & \text { Utility for non-cirrhotic CHB } \\
\text { patient } \\
\text { - } \quad \text { Exclusively objective variables }\end{array}$ & $\begin{array}{ll}- & \text { Ethnically homogenous cohort } \\
- & \text { Three-tier stratification system } \\
\text { - } & \text { Only overt cirrhosis was } \\
& \text { considered }\end{array}$ \\
\hline D²AS Risk score [93] & $\begin{array}{l}\text { HBV DNA } \\
\text { Sex } \\
\text { Age }\end{array}$ & $\begin{array}{ll}\text { - } & \text { Evaluated multiple clinical } \\
\text { indicators of cirrhosis } \\
\text { - } \quad \text { Continuous variables used } \\
\text { - } \quad \text { Common and objective } \\
\text { variables }\end{array}$ & $\begin{array}{ll}\text { - } & \text { Ethnically homogenous cohort } \\
\text { - } & \text { Minimal HBV genotype } \\
\text { diversity } \\
\text { - } \quad \text { Did not evaluate well-known } \\
\text { HCC risk factors, i.e., alcohol } \\
\text { consumption }\end{array}$ \\
\hline
\end{tabular}

${ }^{1}$ IPM: individual prediction model; CU-HCC: Chinese University HCC score; LSM-HCC: liver stiffness measurement-HCC; GAG-HCC: guide with age, gender, HBV DNA, core promoter mutations and cirrhosis; REACH-B: risk estimation for hepatocellular carcinoma in chronic hepatitis B; aMAP score: age, male, albumin-bilirubin, platelets; RWS-HCC: real world risk score for hepatocellular carcinoma; NGM1-HCC: nomogram 1 for HCC risk; NGM2-HCC: nomogram 2 for HCC Risk; LSPS: LS value-spleen diameter to platelet ratio score; AGED: age, gender, HBeAg and HBV DNA levels; $\mathrm{D}^{2} \mathrm{AS}$ : $\mathrm{DNA}^{2}$, age, sex. 
Table 3. Critical Analysis of Treated Patient Risk Assessment Models.

\begin{tabular}{|c|c|c|c|c|}
\hline Name $^{1}$ & Components & & Strengths & Weaknesses \\
\hline PAGE-B [94] & $\begin{array}{l}\text { Age } \\
\text { Sex } \\
\text { Platelets }\end{array}$ & - & $\begin{array}{l}\text { Validated in Asian populations } \\
{[95,96]} \\
\text { Higher AUROC than REACH-B in } \\
\text { Asian CHB patients [97] } \\
\text { Multiple categories for each } \\
\text { variable } \\
\text { Common and objective variables }\end{array}$ & $\begin{array}{ll}\text { - } & \text { Created using Caucasian } \\
\text { dataset } \\
\text { - }\end{array}$ \\
\hline mREACH-B [98] & $\begin{array}{l}\text { Gender } \\
\text { Age } \\
\text { ALT } \\
\text { HBeAg } \\
\text { LSM }\end{array}$ & - & $\begin{array}{l}\text { TE LSM more accurate than U/S } \\
{[79,80]} \\
\text { Use of LSM values more likely to be } \\
\text { accurate for treated patients } \\
\text { Validated in treatment } \\
\text { heterogenous cohort [99] }\end{array}$ & $\begin{array}{l}\text { Retained majority of issues from } \\
\text { REACH-B }\end{array}$ \\
\hline AASL-HCC [100] & $\begin{array}{l}\text { Age } \\
\text { Albumin } \\
\text { Sex } \\
\text { Cirrhosis }\end{array}$ & - & $\begin{array}{l}\text { Comprehensive cirrhosis diagnosis } \\
\text { Higher accuracy for predicting } \\
\text { 10-year risk of developing HCC } \\
\text { than CU-HCC, GAG-HCC, } \\
\text { REACH-B, Page-B }\end{array}$ & $\begin{array}{ll}\text { - } & \text { Ethnically homogenous cohort } \\
\text { - } & \text { Three-tier stratification strategy } \\
\text { - } & \text { Homogenous HBV-C dominant } \\
& \text { genotype cohort }\end{array}$ \\
\hline CAMD [101] & $\begin{array}{l}\text { Cirrhosis } \\
\text { Age } \\
\text { Sex } \\
\text { Diabetes }\end{array}$ & - & $\begin{array}{l}\text { Higher 5-year AUROC than } \\
\text { mPAGE-B, PAGE-B in Korean } \\
\text { population [102] } \\
\text { Different national cohorts for } \\
\text { development and validation } \\
\text { Comprehensive cirrhosis diagnosis }\end{array}$ & $\begin{array}{ll}\text { - } & \text { Ethnically homogenous cohort } \\
\text { - } & \text { Three-tier stratification strategy } \\
\text { - } & \text { Limited to clinically diabetic } \\
\text { patients } \\
\text { - } \\
\text { No evidence for support in } \\
\text { populations with high diabetes } \\
\text { prevalence, i.e., South Asian }\end{array}$ \\
\hline REAL-B [103] & $\begin{array}{l}\text { Sex } \\
\text { Age } \\
\text { Alcohol } \\
\text { Cirrhosis } \\
\text { Diabetes } \\
\text { Baseline Platelet } \\
\text { Count } \\
\text { Baseline AFP }\end{array}$ & - & $\begin{array}{l}\text { Study population included } 8 \\
\text { different Asian ethnicities } \\
\text { One of the largest cohorts }(\mathrm{n}=5356) \\
\text { When compared to CAMD, had a } \\
\text { better predictive value up to } 10 \\
\text { years } \\
\text { Consistently capable in population } \\
\text { with varying treatment type } \\
\text { In external validation, had greater } \\
\text { discriminative performance than } \\
\text { REACH-B, CU-HCC, GAG-HCC, } \\
\text { PAGE-B and mPAGE-B [71] }\end{array}$ & 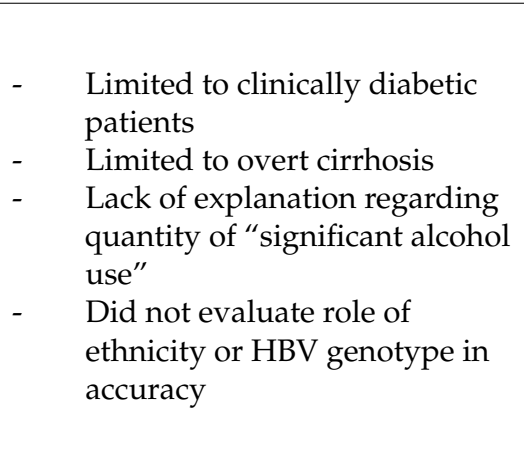 \\
\hline HCC-RESCUE [104] & $\begin{array}{l}\text { Age } \\
\text { Gender } \\
\text { Cirrhosis }\end{array}$ & - & $\begin{array}{l}\text { Validated in Caucasian population } \\
\text { using multiple antiviral therapies } \\
\text { [105] }\end{array}$ & $\begin{array}{ll}\text { - } & \text { Ethnically homogenous cohort } \\
\text { - } & \text { Three-tier stratification strategy } \\
\text { - } & \text { Limited to ultrasound for } \\
& \text { cirrhosis diagnosis }\end{array}$ \\
\hline APA-B [106] & $\begin{array}{l}\text { Age } \\
\text { Platelet Count } \\
\text { Baseline AFP }\end{array}$ & - & $\begin{array}{l}\text { Cohort with heterogenic cirrhosis } \\
\text { profile } \\
\text { Confirmed and advised patients to } \\
\text { avoid using herbal therapies } \\
\text { concurrently } \\
\text { Easy to evaluate and objective }\end{array}$ & $\begin{array}{ll}\text { - } & \text { Ethnically homogenous cohort } \\
\text { - } & \text { Three-tier stratification strategy } \\
\text { - } & \text { Did not account for impact of } \\
\text { other variables on utility of } \\
\text { platelet count as surrogate for } \\
\text { cirrhosis }\end{array}$ \\
\hline
\end{tabular}

${ }^{1}$ PAGE-B: platelets, age, gender-HBV score; mREACH-B: modified REACH-B; AASL-HCC: age, albumin, sex, liver cirrhosis)-HCC score; CAMD: cirrhosis, age, male sex, and diabetes mellitus score; REAL-B: real-world effectiveness from the Asia Pacific rim liver consortium for HBV; HCC-RESCUE: HCC-risk estimating score in CHB patients under entecavir; APA-B: age, platelet counts, and alpha-fetoprotein.

Another area of difference between risk assessment models is the use of a three-tier vs. two-tier stratification of patient risk of developing HCC. While three-tier models are more likely to be statistically accurate than two-tier models, given they allow for a greater degree of objectivity over the data being analyzed, they are limited in their potential utility. 
Protocols in practice for patients with CHB [107] essentially culminate in a binary decision, and it must be determined whether the patient would be included in a screening protocol or not. Ultimately, three-tier models may have limited clinical applicability, as many of the systems in place for screening patients are not designed to have separate protocols for patients who are "high risk" vs. those categorized as "medium risk". Thus, having a paralleled stratification of outcome and model is beneficial for ease of use, and mitigates confusion on how patients should be stratified into surveillance vs. screening.

A limitation of most existing risk scores is a lack of discrimination between the stages of fibrosis beyond a diagnosis of overt cirrhosis. Studies have demonstrated a similar 5-year HCC probability for patients with a histopathological diagnosis of cirrhosis and those with a diagnosis of advanced fibrosis [108], elucidating the need for a more nuanced approach to fibrosis when developing a risk score. An improved assessment of the degree of fibrosis may help improve the cost effectiveness of screening strategies; there are a number of non-invasive techniques for fibrosis evaluation, which have been reviewed in recent guidelines [109]. Further, antiviral-treated patients require accurate staging of fibrosis for updating their risk of developing HCC, as patients with an appropriate treatment response may present with a regression of fibrosis, a positive prognostic indicator for HCC risk [110].

A recent study suggested the utility of a model combining AFP and the FIB-4 model, to predict $\mathrm{HCC}$ outcomes for patients with compensated cirrhosis, due to $\mathrm{CHB}$ being treated with antiviral therapy [111]. However, the novel approach was not compared to existing HCC-CHB risk stratification models, and the reliability of FIB-4 for non-Asian patients with $\mathrm{CHB}$ has also been called into question [112]. To appropriately utilize a FIB-4-like system for $\mathrm{CHB}$, further adaptation may be necessary, with novel modifications being capable of identifying fibrosis, and stratifying HCC risk in the $\mathrm{CHB}$ population currently being investigated [112,113].

\section{Conclusions}

Although screening for HCC in high-risk patients with $\mathrm{CHB}$ is considered the standard of care and has proven benefits, there remains significant gaps in the knowledge base. Outstanding questions include whether alpha-fetoprotein should be a part of the screening program, as well as the risk stratification of patients with $\mathrm{CHB}$ in order to tailor screening programs to those with the highest risk of HCC. From a practical standpoint, investigations on how to develop structured interventions involving the payer, patient, and system to improve adherence to screening programs will be needed to maximize the effectiveness of any of these programs. Ultimately, surveillance programs are necessary for the effective identification of early-stage cancer in high-risk patients. This paper identifies potential areas of improvement to further improve their impact and accuracy in a clinical setting.

Author Contributions: Conceptualization, S.E.C. and M.B.; writing—original draft preparation, Y.S. and S.E.C.; writing - review and editing, M.B. and R.D. All authors have read and agreed to the published version of the manuscript.

Funding: This research received no external funding.

Institutional Review Board Statement: Not applicable.

Informed Consent Statement: Not applicable.

Conflicts of Interest: The authors declare no conflict of interest.

\section{References}

1. Rahib, L.; Wehner, M.R.; Matrisian, L.M.; Nead, K.T. Estimated Projection of US Cancer Incidence and Death to 2040. JAMA Netw. Open 2021, 4, e214708. [CrossRef] [PubMed]

2. Valery, P.C.; Laversanne, M.; Clark, P.J.; Petrick, J.L.; McGlynn, K.A.; Bray, F. Projections of Primary Liver Cancer to 2030 in 30 Countries Worldwide. Hepatology 2018, 67, 600-611. [CrossRef] [PubMed]

3. Mittal, S.; El-Serag, H.B. Epidemiology of Hepatocellular Carcinoma: Consider the Population. J. Clin. Gastroenterol. 2013, 47, S2-S6. [CrossRef] [PubMed] 
4. Sung, H.; Ferlay, J.; Siegel, R.L.; Laversanne, M.; Soerjomataram, I.; Jemal, A.; Bray, F. Global Cancer Statistics 2020: GLOBOCAN Estimates of Incidence and Mortality Worldwide for 36 Cancers in 185 Countries. CA Cancer J. Clin. 2021, 71, 209-249. [CrossRef] [PubMed]

5. Kulik, L.; El-Serag, H.B. Epidemiology and Management of Hepatocellular Carcinoma. Gastroenterology 2019, 156, 477-491. [CrossRef] [PubMed]

6. Zeng, G.; Gill, U.S.; Kennedy, P.T.F. Prioritisation and the Initiation of HCC Surveillance in CHB Patients: Lessons to Learn from the COVID-19 Crisis. Gut 2020, 69, 1907-1912. [CrossRef] [PubMed]

7. Gomaa, A.-I.; Khan, S.-A.; Toledano, M.-B.; Waked, I.; Taylor-Robinson, S.-D. Hepatocellular Carcinoma: Epidemiology, Risk Factors and Pathogenesis. World J. Gastroenterol. 2008, 14, 4300-4308. [CrossRef] [PubMed]

8. Sagnelli, E.; Macera, M.; Russo, A.; Coppola, N.; Sagnelli, C. Epidemiological and Etiological Variations in Hepatocellular Carcinoma. Infection 2020, 48, 7-17. [CrossRef] [PubMed]

9. Wanich, N.; Vilaichone, R.K.; Chotivitayatarakorn, P.; Siramolpiwat, S. High Prevalence of Hepatocellular Carcinoma in Patients with Chronic Hepatitis B Infection in Thailand. Asian Pac. J. Cancer Prev. 2016, 17, 2857-2860.

10. Lemoine, M.; Nayagam, S.; Thursz, M. Viral Hepatitis in Resource-Limited Countries and Access to Antiviral Therapies: Current and Future Challenges. Future Virol. 2013, 8, 371-380. [CrossRef]

11. El-Serag, H.B. Epidemiology of Viral Hepatitis and Hepatocellular Carcinoma. Gastroenterology 2012, 142, 1264-1273. [CrossRef]

12. Chang, M.-H.; Chen, C.-J.; Lai, M.-S.; Hsu, H.-M.; Wu, T.-C.; Kong, M.-S.; Liang, D.-C.; Shau, W.-Y.; Chen, D.-S. Universal Hepatitis B Vaccination in Taiwan and the Incidence of Hepatocellular Carcinoma in Children. N. Engl. J. Med. 1997, 336, 1855-1859. [CrossRef]

13. Singh, A.E.; Plitt, S.S.; Osiowy, C.; Surynicz, K.; Kouadjo, E.; Preiksaitis, J.; Lee, B. Factors Associated with Vaccine Failure and Vertical Transmission of Hepatitis B among a Cohort of Canadian Mothers and Infants. J. Viral Hepat. 2011, 18, 468-473. [CrossRef]

14. Lu, M.; Zhou, Y.; Holmberg, S.D.; Moorman, A.C.; Spradling, P.R.; Teshale, E.H.; Boscarino, J.A.; Daida, Y.G.; Schmidt, M.A.; Li, J.; et al. Trends in Diagnosed Chronic Hepatitis B in a US Health System Population, 2006-2015. Open Forum Infect. Dis. 2019, 6, ofz286. [CrossRef]

15. Lim, J.K.; Nguyen, M.H.; Kim, W.R.; Gish, R.; Perumalswami, P.; Jacobson, I.M. Prevalence of Chronic Hepatitis B Virus Infection in the United States. Am. J. Gastroenterol. 2020, 115, 1429-1438. [CrossRef]

16. Yang, J.D.; Mohammed, H.A.; Harmsen, W.S.; Enders, F.; Gores, G.J.; Roberts, L.R. Recent Trends in the Epidemiology of Hepatocellular Carcinoma in Olmsted County, Minnesota: A US Population-Based Study. J. Clin. Gastroenterol. 2017, 51, 742-748. [CrossRef]

17. Herman, C. What Makes a Screening Exam “Good"? Virtual Mentor VM 2006, 8, 34-37. [CrossRef]

18. Wilson, J.M.G.; Jungner, G. Principles and Practice of Screening for Disease; World Health Organization: Geneva, Switzerland, 1968.

19. Gandhi, S.; Khubchandani, S.; Iyer, R. Quality of Life and Hepatocellular Carcinoma. J. Gastrointest. Oncol. 2014, 5, 296-317. [CrossRef]

20. Coffin, C.S.; Fung, S.K.; Alvarez, F.; Cooper, C.L.; Doucette, K.E.; Fournier, C.; Kelly, E.; Ko, H.H.; Ma, M.M.; Martin, S.R.; et al. Management of Hepatitis B Virus Infection: 2018 Guidelines from the Canadian Association for the Study of Liver Disease and Association of Medical Microbiology and Infectious Disease Canada. Can. Liver J. 2018, 1, 156-217. [CrossRef]

21. European Association for the Study of the Liver EASL Clinical Practice Guidelines: Management of Hepatocellular Carcinoma. J. Hepatol. 2018, 69, 182-236. [CrossRef]

22. Terrault, N.A.; Lok, A.S.F.; McMahon, B.J.; Chang, K.-M.; Hwang, J.P.; Jonas, M.M.; Brown, R.S.; Bzowej, N.H.; Wong, J.B. Update on Prevention, Diagnosis, and Treatment of Chronic Hepatitis B: AASLD 2018 Hepatitis B Guidance. Hepatology 2018, 67, 1560-1599. [CrossRef]

23. Marrero, J.A.; Kulik, L.M.; Sirlin, C.B.; Zhu, A.X.; Finn, R.S.; Abecassis, M.M.; Roberts, L.R.; Heimbach, J.K. Diagnosis, Staging, and Management of Hepatocellular Carcinoma: 2018 Practice Guidance by the American Association for the Study of Liver Diseases. Hepatology 2018, 68, 723-750. [CrossRef]

24. Omata, M.; Cheng, A.-L.; Kokudo, N.; Kudo, M.; Lee, J.M.; Jia, J.; Tateishi, R.; Han, K.-H.; Chawla, Y.K.; Shiina, S.; et al. Asia-Pacific Clinical Practice Guidelines on the Management of Hepatocellular Carcinoma: A 2017 Update. Hepatol. Int. 2017, 11, 317-370. [CrossRef]

25. Yang, B.; Zhang, B.; Xu, Y.; Wang, W.; Shen, Y.; Zhang, A.; Xu, Z. Prospective Study of Early Detection for Primary Liver Cancer. J. Cancer Res. Clin. Oncol. 1997, 123, 357-360. [CrossRef] [PubMed]

26. Zhang, B.-H.; Yang, B.-H.; Tang, Z.-Y. Randomized Controlled Trial of Screening for Hepatocellular Carcinoma. J. Cancer Res. Clin. Oncol. 2004, 130, 417-422. [CrossRef] [PubMed]

27. Kansagara, D.; Papak, J.; Pasha, A.S.; O’Neil, M.; Freeman, M.; Relevo, R.; Quiñones, A.; Motu'apuaka, M.; Jou, J.H. Screening for Hepatocellular Carcinoma in Chronic Liver Disease: A Systematic Review. Ann. Intern. Med. 2014, 161, 261. [CrossRef] [PubMed]

28. Chen, J.-G.; Parkin, D.M.; Chen, Q.-G.; Lu, J.-H.; Shen, Q.-J.; Zhang, B.-C.; Zhu, Y.-R. Screening for Liver Cancer: Results of a Randomised Controlled Trial in Qidong, China. J. Med. Screen. 2003, 10, 204-209. [CrossRef] [PubMed]

29. Xie, D.-Y.; Ren, Z.-G.; Zhou, J.; Fan, J.; Gao, Q. 2019 Chinese Clinical Guidelines for the Management of Hepatocellular Carcinoma: Updates and Insights. Hepatobiliary Surg. Nutr. 2020, 9, 452-463. [CrossRef]

30. Singal, A.G.; Pillai, A.; Tiro, J. Early Detection, Curative Treatment, and Survival Rates for Hepatocellular Carcinoma Surveillance in Patients with Cirrhosis: A Meta-Analysis. PLoS Med. 2014, 11, e1001624. [CrossRef] 
31. Thein, H.-H.; Yi, Q.; Dore, G.J.; Krahn, M.D. Natural History of Hepatitis C Virus Infection in HIV-Infected Individuals and the Impact of HIV in the Era of Highly Active Antiretroviral Therapy: A Meta-Analysis. AIDS Lond. Engl. 2008, 22, $1979-1991$. [CrossRef]

32. Singal, A.G.; Tiro, J.; Li, X.; Adams-Huet, B.; Chubak, J. Hepatocellular Carcinoma Surveillance Among Patients With Cirrhosis in a Population-Based Integrated Health Care Delivery System. J. Clin. Gastroenterol. 2017, 51, 650-655. [CrossRef]

33. Choi, D.T.; Kum, H.-C.; Park, S.; Ohsfeldt, R.L.; Shen, Y.; Parikh, N.D.; Singal, A.G. Hepatocellular Carcinoma Screening Is Associated With Increased Survival of Patients With Cirrhosis. Clin. Gastroenterol. Hepatol. 2019, 17, 976-987. [CrossRef]

34. Tong, M.J.; Rosinski, A.A.; Huynh, C.T.; Raman, S.S.; Lu, D.S.K. Long-Term Survival after Surveillance and Treatment in Patients with Chronic Viral Hepatitis and Hepatocellular Carcinoma. Hepatol. Commun. 2017, 1, 595-608. [CrossRef]

35. Moon, A.M.; Weiss, N.S.; Beste, L.A.; Su, F.; Ho, S.B.; Jin, G.-Y.; Lowy, E.; Berry, K.; Ioannou, G.N. No Association Between Screening for Hepatocellular Carcinoma and Reduced Cancer-Related Mortality in Patients With Cirrhosis. Gastroenterology 2018, 155, 1128-1139. [CrossRef]

36. PDQ. Screening and Prevention Editorial Board Liver (Hepatocellular) Cancer Screening (PDQ®): Health Professional Version. In PDQ Cancer Information Summaries; National Cancer Institute (US): Bethesda, MD, USA, 2002.

37. Kanwal, F.; Singal, A.G. Surveillance for Hepatocellular Carcinoma: Current Best Practice and Future Direction. Gastroenterology 2019, 157, 54-64. [CrossRef] [PubMed]

38. Goutté, N.; Sogni, P.; Bendersky, N.; Barbare, J.C.; Falissard, B.; Farges, O. Geographical Variations in Incidence, Management and Survival of Hepatocellular Carcinoma in a Western Country. J. Hepatol. 2017, 66, 537-544. [CrossRef]

39. Taketa, K. Alpha-Fetoprotein: Reevaluation in Hepatology. Hepatology 1990, 12, 1420-1432. [CrossRef]

40. Galle, P.R.; Foerster, F.; Kudo, M.; Chan, S.L.; Llovet, J.M.; Qin, S.; Schelman, W.R.; Chintharlapalli, S.; Abada, P.B.; Sherman, M.; et al. Biology and Significance of Alpha-fetoprotein in Hepatocellular Carcinoma. Liver Int. 2019, 39, 2214-2229. [CrossRef]

41. Takikawa, Y.; Suzuki, K. Is AFP a New Reliable Marker of Liver Regeneration in Acute Hepatic Failure? J. Gastroenterol. 2002, 37, 681-682. [CrossRef]

42. Patil, M.; Sheth, K.A.; Adarsh, C.K. Elevated Alpha Fetoprotein, No Hepatocellular Carcinoma. J. Clin. Exp. Hepatol. 2013, 3, 162-164. [CrossRef]

43. Tzartzeva, K.; Obi, J.; Rich, N.E.; Parikh, N.D.; Marrero, J.A.; Yopp, A.; Waljee, A.K.; Singal, A.G. Surveillance Imaging and Alpha Fetoprotein for Early Detection of Hepatocellular Carcinoma in Patients With Cirrhosis: A Meta-Analysis. Gastroenterology 2018, 154, 1706-1718. [CrossRef] [PubMed]

44. Frenette, C.T.; Isaacson, A.J.; Bargellini, I.; Saab, S.; Singal, A.G. A Practical Guideline for Hepatocellular Carcinoma Screening in Patients at Risk. Mayo Clin. Proc. Innov. Qual. Outcomes 2019, 3, 302-310. [CrossRef] [PubMed]

45. Bruix, J.; Sherman, M. American Association for the Study of Liver Diseases Management of Hepatocellular Carcinoma: An Update. Hepatology 2011, 53, 1020-1022. [CrossRef] [PubMed]

46. Alfaiate, D.; Clément, S.; Gomes, D.; Goossens, N.; Negro, F. Chronic Hepatitis D and Hepatocellular Carcinoma: A Systematic Review and Meta-Analysis of Observational Studies. J. Hepatol. 2020, 73, 533-539. [CrossRef]

47. Farci, P.; Niro, G.A.; Zamboni, F.; Diaz, G. Hepatitis D Virus and Hepatocellular Carcinoma. Viruses 2021, 13, 830. [CrossRef]

48. Cho, L.Y.; Yang, J.J.; Ko, K.-P.; Park, B.; Shin, A.; Lim, M.K.; Oh, J.-K.; Park, S.; Kim, Y.J.; Shin, H.-R.; et al. Coinfection of Hepatitis B and C Viruses and Risk of Hepatocellular Carcinoma: Systematic Review and Meta-Analysis. Int. J. Cancer 2011, 128, 176-184. [CrossRef]

49. Kim, H.N. Chronic Hepatitis B and HIV Coinfection: A Continuing Challenge in the Era of Antiretroviral Therapy. Curr. Hepatol. Rep. 2020, 19, 345-353. [CrossRef]

50. Merchante, N.; Rodríguez-Fernández, M.; Pineda, J.A. Screening for Hepatocellular Carcinoma in HIV-Infected Patients: Current Evidence and Controversies. Curr. HIV/AIDS Rep. 2020, 17, 6-17. [CrossRef]

51. Nguyen, A.L.T.; Nguyen, H.T.T.; Yee, K.C.; Palmer, A.J.; Blizzard, C.L.; de Graaff, B. A Systematic Review and Narrative Synthesis of Health Economic Evaluations of Hepatocellular Carcinoma Screening Strategies. Value Health 2021, 24, 733-743. [CrossRef]

52. Sangmala, P.; Chaikledkaew, U.; Tanwandee, T.; Pongchareonsuk, P. Economic Evaluation and Budget Impact Analysis of the Surveillance Program for Hepatocellular Carcinoma in Thai Chronic Hepatitis B Patients. Asian Pac. J. Cancer Prev. 2014, 15, 8993-9004. [CrossRef]

53. Kang, J.Y.; Lee, T.P.; Yap, I.; Lun, K.C. Analysis of Cost-Effectiveness of Different Strategies for Hepatocellular Carcinoma Screening in Hepatitis B Virus Carriers. J. Gastroenterol. Hepatol. 1992, 7, 463-468. [CrossRef]

54. Lam, C. Screening for Hepatocellular Carcinoma (HCC): Is It Cost-Effective? Hong Kong Pract. 2000, $22,546-551$.

55. Robotin, M.C.; Kansil, M.; Howard, K.; George, J.; Tipper, S.; Dore, G.J.; Levy, M.; Penman, A.G. Antiviral Therapy for Hepatitis B-Related Liver Cancer Prevention Is More Cost-Effective than Cancer Screening. J. Hepatol. 2009, 50, 990-998. [CrossRef]

56. Chang, Y.; Lairson, D.R.; Chan, W.; Lu, S.-N.; Aoki, N. Cost-Effectiveness of Screening for Hepatocellular Carcinoma among Subjects at Different Levels of Risk. J. Eval. Clin. Pract. 2011, 17, 261-267. [CrossRef]

57. Parikh, N.D.; Singal, A.G.; Hutton, D.W.; Tapper, E.B. Cost-Effectiveness of Hepatocellular Carcinoma Surveillance: An Assessment of Benefits and Harms. Am. J. Gastroenterol. 2020, 115, 1642-1649. [CrossRef]

58. Wolf, E.; Rich, N.E.; Marrero, J.A.; Parikh, N.D.; Singal, A.G. Use of Hepatocellular Carcinoma Surveillance in Patients With Cirrhosis: A Systematic Review and Meta-Analysis. Hepatology 2021, 73, 713-725. [CrossRef] 
59. Singal, A.G.; Yopp, A.C.; Gupta, S.; Skinner, C.S.; Halm, E.A.; Okolo, E.; Nehra, M.; Lee, W.M.; Marrero, J.A.; Tiro, J.A. Failure Rates in the Hepatocellular Carcinoma Surveillance Process. Cancer Prev. Res. Phila. Pa 2012, 5, 1124-1130. [CrossRef]

60. Marquardt, P.; Liu, P.; Immergluck, J.; Olivares, J.; Arroyo, A.; Rich, N.E.; Parikh, N.D.; Yopp, A.C.; Singal, A.G. Hepatocellular Carcinoma Screening Process Failures in Patients with Cirrhosis. Hepatol. Commun. 2021. [CrossRef]

61. Bharadwaj, S.; Gohel, T.D. Perspectives of Physicians Regarding Screening Patients at Risk of Hepatocellular Carcinoma. Gastroenterol. Rep. 2016, 4, 237-240. [CrossRef]

62. Singal, A.G.; Li, X.; Tiro, J.; Kandunoori, P.; Adams-Huet, B.; Nehra, M.S.; Yopp, A. Racial, Social, and Clinical Determinants of Hepatocellular Carcinoma Surveillance. Am. J. Med. 2015, 128, 90.e1-90.e7. [CrossRef]

63. Farvardin, S.; Patel, J.; Khambaty, M.; Yerokun, O.A.; Mok, H.; Tiro, J.A.; Yopp, A.C.; Parikh, N.D.; Marrero, J.A.; Singal, A.G. Patient-Reported Barriers Are Associated with Lower Hepatocellular Carcinoma Surveillance Rates in Patients with Cirrhosis. Hepatology 2017, 65, 875-884. [CrossRef] [PubMed]

64. Goldberg, D.S.; Taddei, T.H.; Serper, M.; Mehta, R.; Dieperink, E.; Aytaman, A.; Baytarian, M.; Fox, R.; Hunt, K.; Pedrosa, M.; et al. Identifying Barriers to Hepatocellular Carcinoma Surveillance in a National Sample of Patients with Cirrhosis. Hepatology 2017, 65, 864-874. [CrossRef] [PubMed]

65. Simmons, O.L.; Feng, Y.; Parikh, N.D.; Singal, A.G. Primary Care Provider Practice Patterns and Barriers to Hepatocellular Carcinoma Surveillance. Clin. Gastroenterol. Hepatol. 2019, 17, 766-773. [CrossRef] [PubMed]

66. Dalton-Fitzgerald, E.; Tiro, J.; Kandunoori, P.; Halm, E.A.; Yopp, A.; Singal, A.G. Practice Patterns and Attitudes of Primary Care Providers and Barriers to Surveillance of Hepatocellular Carcinoma in Patients with Cirrhosis. Clin. Gastroenterol. Hepatol. Off. Clin. Pract. J. Am. Gastroenterol. Assoc. 2015, 13, 791-798. [CrossRef]

67. Singal, A.G.; Tiro, J.A.; Murphy, C.C.; Marrero, J.A.; McCallister, K.; Fullington, H.; Mejias, C.; Waljee, A.K.; Pechero Bishop, W.; Santini, N.O.; et al. Mailed Outreach Invitations Significantly Improve HCC Surveillance Rates in Patients With Cirrhosis: A Randomized Clinical Trial. Hepatology 2019, 69, 121-130. [CrossRef]

68. Nazareth, S.; Leembruggen, N.; Tuma, R.; Chen, S.-L.; Rao, S.; Kontorinis, N.; Cheng, W. Nurse-Led Hepatocellular Carcinoma Surveillance Clinic Provides an Effective Method of Monitoring Patients with Cirrhosis. Int. J. Nurs. Pract. 2016, 22 (Suppl. 2), S3-S11. [CrossRef]

69. Kennedy, N.A.; Rodgers, A.; Altus, R.; McCormick, R.; Wundke, R.; Wigg, A.J. Optimisation of Hepatocellular Carcinoma Surveillance in Patients with Viral Hepatitis: A Quality Improvement Study. Intern. Med. J. 2013, 43, 772-777. [CrossRef]

70. Farrell, C.; Halpen, A.; Cross, T.J.S.; Richardson, P.D.; Johnson, P.; Joekes, E.C. Ultrasound Surveillance for Hepatocellular Carcinoma: Service Evaluation of a Radiology-Led Recall System in a Tertiary-Referral Centre for Liver Diseases in the UK. Clin. Radiol. 2017, 72, 338.e11-338.e17. [CrossRef]

71. Wu, S.; Zeng, N.; Sun, F.; Zhou, J.; Wu, X.; Sun, Y.; Wang, B.; Zhan, S.; Kong, Y.; Jia, J.; et al. Hepatocellular Carcinoma Prediction Models in Chronic Hepatitis B: A Systematic Review of 14 Models and External Validation. Clin. Gastroenterol. Hepatol. 2021. [CrossRef]

72. Congly, S.E.; Brownfield, K.A. Distinguishing between Sex and Gender Is Critical for Research in Transplantation. Transplantation 2019, 104, e57. [CrossRef]

73. Han, K.-H.; Ahn, S.H. How to Predict HCC Development in Patients with Chronic B Viral Liver Disease? Intervirology 2005, 48, 23-28. [CrossRef]

74. Wong, V.W.S.; Chan, S.L.; Mo, F.; Chan, T.C.; Loong, H.H.F.; Wong, G.L.H.; Lui, Y.Y.N.; Chan, A.T.C.; Sung, J.J.Y.; Yeo, W.; et al. Clinical Scoring System to Predict Hepatocellular Carcinoma in Chronic Hepatitis B Carriers. J. Clin. Oncol. 2010, 28, 1660-1665. [CrossRef]

75. Chan, H.L.Y.; Hui, A.Y.; Wong, M.L.; Tse, A.M.L.; Hung, L.C.T.; Wong, V.W.S.; Sung, J.J.Y. Genotype C Hepatitis B Virus Infection Is Associated with an Increased Risk of Hepatocellular Carcinoma. Gut 2004, 53, 1494-1498. [CrossRef]

76. Abu-Amara, M.; Cerocchi, O.; Malhi, G.; Sharma, S.; Yim, C.; Shah, H.; Wong, D.K.; Janssen, H.L.A.; Feld, J.J. The Applicability of Hepatocellular Carcinoma Risk Prediction Scores in a North American Patient Population with Chronic Hepatitis B Infection. Gut 2016, 65, 1347-1358. [CrossRef]

77. Yip, T.C.-F.; Hui, V.W.-K.; Tse, Y.-K.; Wong, G.L.-H. Statistical Strategies for HCC Risk Prediction Models in Patients with Chronic Hepatitis B. Hepatoma Res. 2021, 2021, 7. [CrossRef]

78. Wong, G.L.-H.; Chan, H.L.-Y.; Wong, C.K.-Y.; Leung, C.; Chan, C.Y.; Ho, P.P.-L.; Chung, V.C.-Y.; Chan, Z.C.-Y.; Tse, Y.-K.; Chim, A.M.-L.; et al. Liver Stiffness-Based Optimization of Hepatocellular Carcinoma Risk Score in Patients with Chronic Hepatitis B. J. Hepatol. 2014, 60, 339-345. [CrossRef]

79. Ganne-Carrié, N.; Ziol, M.; de Ledinghen, V.; Douvin, C.; Marcellin, P.; Castera, L.; Dhumeaux, D.; Trinchet, J.-C.; Beaugrand, M. Accuracy of Liver Stiffness Measurement for the Diagnosis of Cirrhosis in Patients with Chronic Liver Diseases. Hepatology 2006, 44, 1511-1517. [CrossRef]

80. Wong, V.W.-S.; Janssen, H.L.A. Can We Use HCC Risk Scores to Individualize Surveillance in Chronic Hepatitis B Infection? J. Hepatol. 2015, 63, 722-732. [CrossRef]

81. Yuen, M.-F.; Tanaka, Y.; Fong, D.Y.-T.; Fung, J.; Wong, D.K.-H.; Yuen, J.C.-H.; But, D.Y.-K.; Chan, A.O.-O.; Wong, B.C.-Y.; Mizokami, M.; et al. Independent Risk Factors and Predictive Score for the Development of Hepatocellular Carcinoma in Chronic Hepatitis B. J. Hepatol. 2009, 50, 80-88. [CrossRef] 
82. Yang, H.I.; Yuen, M.F.; Chan, H.L.Y.; Han, K.H.; Chen, P.J.; Kim, D.Y.; Ahn, S.H.; Chen, C.J.; Wong, V.W.S.; Seto, W.K. Risk Estimation for Hepatocellular Carcinoma in Chronic Hepatitis B (REACH-B): Development and Validation of a Predictive Score. Lancet Oncol. 2011, 12, 568-574. [CrossRef]

83. Chen, T.M.; Chang, C.C.; Huang, P.T.; Wen, C.F.; Lin, C.C. Performance of Risk Estimation for Hepatocellular Carcinoma in Chronic Hepatitis B (REACH-B) Score in Classifying Treatment Eligibility under 2012 Asian Pacific Association for the Study of the Liver (APASL) Guideline for Chronic Hepatitis B Patients. Aliment. Pharmacol. Ther. 2013, 37, 243-251. [CrossRef]

84. Magalhães-Costa, P.; Lebre, L.; Peixe, P.; Santos, S.; Chagas, C. Carcinoma Hepatocelular Em Doentes Com Infecção Crónica Pelo Vírus Da Hepatite B Sob Análogos Dos Nucleós(t)Idos de $3^{\text {a }}$ Geração: Factores de Risco e o Desempenho de Um Score de Risco. GE Port. J. Gastroenterol. 2016, 23, 233-242. [CrossRef]

85. Fan, R.; Papatheodoridis, G.; Sun, J.; Innes, H.; Toyoda, H.; Xie, Q.; Mo, S.; Sypsa, V.; Guha, I.N.; Kumada, T.; et al. AMAP Risk Score Predicts Hepatocellular Carcinoma Development in Patients with Chronic Hepatitis. J. Hepatol. 2020, 73, 1368-1378. [CrossRef] [PubMed]

86. Alempijevic, T.M.; Stojkovic Lalosevic, M.; Dumic, I.; Jocic, N.; Markovic, A.P.; Dragasevic, S.; Jovicic, I.; Lukic, S.; Popovic, D.; Milosavljevic, T. Diagnostic Accuracy of Platelet Count and Platelet Indices in Noninvasive Assessment of Fibrosis in Nonalcoholic Fatty Liver Disease Patients. Can. J. Gastroenterol. Hepatol. 2017, 2017. [CrossRef]

87. Shiha, G.; Mikhail, N.; Soliman, R. External Validation of AMAP Risk Score in Patients with Chronic Hepatitis C Genotype 4 and Cirrhosis Who Achieved SVR Following DAAs. J. Hepatol. 2020, 74, 994-996. [CrossRef]

88. Poh, Z.; Shen, L.; Yang, H.-I.; Seto, W.-K.; Wong, V.W.; Lin, C.Y.; Goh, B.-B.G.; Chang, P.-E.J.; Chan, H.L.-Y.; Yuen, M.-F.; et al. Real-World Risk Score for Hepatocellular Carcinoma (RWS-HCC): A Clinically Practical Risk Predictor for HCC in Chronic Hepatitis B. Gut 2016, 65, 887-888. [CrossRef]

89. Yang, H.-I.; Sherman, M.; Su, J.; Chen, P.-J.; Liaw, Y.-F.; Iloeje, U.H.; Chen, C.-J. Nomograms for Risk of Hepatocellular Carcinoma in Patients with Chronic Hepatitis B Virus Infection. J. Clin. Oncol. 2010, 28, 2437-2444. [CrossRef]

90. Shin, S.H.; Kim, S.U.; Park, J.Y.; Kim, D.Y.; Ahn, S.H.; Han, K.-H.; Kim, B.K. Liver Stiffness-Based Model for Prediction of Hepatocellular Carcinoma in Chronic Hepatitis B Virus Infection: Comparison with Histological Fibrosis. Liver Int. 2015, 35, 1054-1062. [CrossRef]

91. Kim, B.K.; Park, Y.N.; Kim, D.Y.; Park, J.Y.; Chon, C.Y.; Han, K.-H.; Ahn, S.H. Risk Assessment of Development of Hepatic Decompensation in Histologically Proven Hepatitis B Viral Cirrhosis Using Liver Stiffness Measurement. Digestion 2012, 85, 219-227. [CrossRef] [PubMed]

92. Fan, C.; Li, M.; Gan, Y.; Chen, T.; Sun, Y.; Lu, J.; Wang, J.; Jin, Y.; Lu, J.; Qian, G.; et al. A Simple AGED Score for Risk Classification of Primary Liver Cancer: Development and Validation with Long-Term Prospective HBsAg-Positive Cohorts in Qidong, China. Gut 2019, 68, 948-949. [CrossRef] [PubMed]

93. Sinn, D.H.; Lee, J.-H.; Kim, K.; Ahn, J.H.; Lee, J.H.; Kim, J.H.; Lee, D.H.; Yoon, J.-H.; Kang, W.; Gwak, G.-Y.; et al. A Novel Model for Predicting Hepatocellular Carcinoma Development in Patients with Chronic Hepatitis B and Normal Alanine Aminotransferase Levels. Gut Liver 2017, 11, 528-534. [CrossRef]

94. Papatheodoridis, G.; Dalekos, G.; Sypsa, V.; Yurdaydin, C.; Buti, M.; Goulis, J.; Calleja, J.L.; Chi, H.; Manolakopoulos, S.; Mangia, G.; et al. PAGE-B Predicts the Risk of Developing Hepatocellular Carcinoma in Caucasians with Chronic Hepatitis B on 5-Year Antiviral Therapy. J. Hepatol. 2016, 64, 800-806. [CrossRef]

95. Kirino, S.; Tamaki, N.; Kaneko, S.; Kurosaki, M.; Inada, K.; Yamashita, K.; Osawa, L.; Hayakawa, Y.; Sekiguchi, S.; Watakabe, K.; et al. Validation of Hepatocellular Carcinoma Risk Scores in Japanese Chronic Hepatitis B Cohort Receiving Nucleot(s)Ide Analog. J. Gastroenterol. Hepatol. Aust. 2020, 35, 1595-1601. [CrossRef]

96. Yip, T.C.F.; Wong, G.L.H.; Wong, V.W.S.; Tse, Y.K.; Liang, L.Y.; Hui, V.W.K.; Lee, H.W.; Lui, G.C.Y.; Chan, H.L.Y. Reassessing the Accuracy of PAGE-B-Related Scores to Predict Hepatocellular Carcinoma Development in Patients with Chronic Hepatitis B. J. Hepatol. 2020, 72, 847-854. [CrossRef]

97. Kim, M.N.; Hwang, S.G.; Rim, K.S.; Kim, B.K.; Park, J.Y.; Kim, D.Y.; Ahn, S.H.; Han, K.H.; Kim, S.U. Validation of PAGE-B Model in Asian Chronic Hepatitis B Patients Receiving Entecavir or Tenofovir. Liver Int. 2017, 37, 1788-1795. [CrossRef]

98. Lee, H.W.; Yoo, E.J.; Kim, B.K.; Kim, S.U.; Park, J.Y.; Kim, D.Y.; Ahn, S.H.; Han, K.-H. Prediction of Development of Liver-Related Events by Transient Elastography in Hepatitis B Patients With Complete Virological Response on Antiviral Therapy. Am. J. Gastroenterol. 2014, 109, 1241-1249. [CrossRef]

99. Seo, Y.S.; Jang, B.K.; Um, S.H.; Hwang, J.S.; Han, K.-H.; Kim, S.G.; Lee, K.S.; Kim, S.U.; Kim, Y.S.; Lee, J.I. Validation of Risk Prediction Models for the Development of HBV-Related HCC: A Retrospective Multi-Center 10-Year Follow-up Cohort Study. Oncotarget 2017, 8, 113213-113224. [CrossRef]

100. Yu, J.H.; Suh, Y.J.; Jin, Y.-J.; Heo, N.-Y.; Jang, J.W.; You, C.R.; An, H.Y.; Lee, J.-W. Prediction Model for Hepatocellular Carcinoma Risk in Treatment-Naive Chronic Hepatitis B Patients Receiving Entecavir/Tenofovir. Eur. J. Gastroenterol. Hepatol. 2019, 31, 865-872. [CrossRef]

101. Hsu, Y.-C.; Yip, T.C.-F.; Ho, H.J.; Wong, V.W.-S.; Huang, Y.-T.; El-Serag, H.B.; Lee, T.-Y.; Wu, M.-S.; Lin, J.-T.; Wong, G.L.-H.; et al. Development of a Scoring System to Predict Hepatocellular Carcinoma in Asians on Antivirals for Chronic Hepatitis B. J. Hepatol. 2018, 69, 278-285. [CrossRef] 
102. Kim, S.U.; Seo, Y.S.; Lee, H.A.; Kim, M.N.; Kim, E.H.; Kim, H.Y.; Lee, Y.R.; Lee, H.W.; Park, J.Y.; Kim, D.Y.; et al. Validation of the CAMD Score in Patients With Chronic Hepatitis B Virus Infection Receiving Antiviral Therapy. Clin. Gastroenterol. Hepatol. 2020, 18, 693-699. [CrossRef]

103. Yang, H.-I.; Yeh, M.-L.; Wong, G.L.; Peng, C.-Y.; Chen, C.-H.; Trinh, H.N.; Cheung, K.-S.; Xie, Q.; Su, T.-H.; Kozuka, R.; et al. Real-World Effectiveness From the Asia Pacific Rim Liver Consortium for HBV Risk Score for the Prediction of Hepatocellular Carcinoma in Chronic Hepatitis B Patients Treated With Oral Antiviral Therapy. J. Infect. Dis. 2020, 221, 389-399. [CrossRef] [PubMed]

104. Sohn, W.; Cho, J.-Y.; Kim, J.H.; Lee, J.I.; Kim, H.J.; Woo, M.-A.; Jung, S.-H.; Paik, Y.-H. Risk Score Model for the Development of Hepatocellular Carcinoma in Treatment-Naïve Patients Receiving Oral Antiviral Treatment for Chronic Hepatitis B. Clin. Mol. Hepatol. 2017, 23, 170-178. [CrossRef] [PubMed]

105. Güzelbulut, F.; Gökçen, P.; Can, G.; Adalı, G.; Değirmenci Saltürk, A.G.; Bahadır, Ö.; Özdil, K.; Doğanay, H.L. Validation of the HCC-RESCUE Score to Predict Hepatocellular Carcinoma Risk in Caucasian Chronic Hepatitis B Patients under Entecavir or Tenofovir Therapy. J. Viral Hepat. 2021, 28, 826-836. [CrossRef] [PubMed]

106. Chen, C.-H.; Lee, C.-M.; Lai, H.-C.; Hu, T.-H.; Su, W.-P.; Lu, S.-N.; Lin, C.-H.; Hung, C.-H.; Wang, J.-H.; Lee, M.-H.; et al. Prediction Model of Hepatocellular Carcinoma Risk in Asian Patients with Chronic Hepatitis B Treated with Entecavir. Oncotarget 2017, 8, 92431-92441. [CrossRef]

107. Heimbach, J.K.; Kulik, L.M.; Finn, R.S.; Sirlin, C.B.; Abecassis, M.M.; Roberts, L.R.; Zhu, A.X.; Murad, M.H.; Marrero, J.A. AASLD Guidelines for the Treatment of Hepatocellular Carcinoma. Hepatology 2018, 67, 358-380. [CrossRef]

108. Axley, P.; Mudumbi, S.; Sarker, S.; Kuo, Y.-F.; Singal, A. Patients with Stage 3 Compared to Stage 4 Liver Fibrosis Have Lower Frequency of and Longer Time to Liver Disease Complications. PLoS ONE 2018, 13, e197117. [CrossRef]

109. Berzigotti, A.; Tsochatzis, E.; Boursier, J.; Castera, L.; Cazzagon, N.; Friedrich-Rust, M.; Petta, S.; Thiele, M. EASL Clinical Practice Guidelines on Non-Invasive Tests for Evaluation of Liver Disease Severity and Prognosis-2021 Update. J. Hepatol. 2021. [CrossRef]

110. Udompap, P.; Kim, W.R. Development of Hepatocellular Carcinoma in Patients With Suppressed Viral Replication: Changes in Risk Over Time. Clin. Liver Dis. 2020, 15, 85-90. [CrossRef]

111. Chiang, H.-H.; Lee, C.-M.; Hu, T.-H.; Hung, C.-H.; Wang, J.-H.; Lu, S.-N.; Lai, H.-C.; Su, W.-P.; Lin, C.-H.; Peng, C.-Y.; et al. A Combination of the On-Treatment FIB-4 and Alpha-Foetoprotein Predicts Clinical Outcomes in Cirrhotic Patients Receiving Entecavir. Liver Int. 2018, 38, 1997-2005. [CrossRef]

112. Demir, M.; Grünewald, F.; Lang, S.; Schramm, C.; Bowe, A.; Mück, V.; Kütting, F.; Goeser, T.; Steffen, H.-M. Elevated Liver Fibrosis Index FIB-4 Is Not Reliable for HCC Risk Stratification in Predominantly Non-Asian CHB Patients. Medicine (Baltimore) 2016, 95, e4602. [CrossRef]

113. Metwally, K.; Elsabaawy, M.; Abdel-Samiee, M.; Morad, W.; Ehsan, N.; Abdelsameea, E. FIB-5 versus FIB-4 Index for Assessment of Hepatic Fibrosis in Chronic Hepatitis B Affected Patients. Clin. Exp. Hepatol. 2020, 6, 335-338. [CrossRef] 